ISSN: 2148-2586

\title{
A NEW APPROACH IN ORGANIZATIONAL PSYCHOLOGY: SELF- EXPECTATION FOR ORGANIZATIONAL IMPROVEMENT AND A SCALE DEVELOPMENT STUDY
}

\author{
Mukaddes YEŞİLKAYA ${ }^{1}$ \\ Gökhan KERSE²
}

\author{
Received Date (Başvuru Tarihi): 02/11/2019 \\ Accepted Date (Kabul Tarihi): 10/12/2019 \\ Published Date (Yayın Tarihi): 25/12/2019
}

\section{ABSTRACT}

The aim of this research is to bring the concept of Self-Expectation for Organizational Improvement" (SEOI) to the field of organizational psychology and to develop a measurement tool by forming the theoreticalempirical background of this concept. In the study, firstly, the theoretical framework related to the concept of SEOI was established and the concept of SEOI defined as follows; independent of the planned actions of the organization management, self-expectations that the individual has designed completely in his/her own mind and that there will be positive improvements and developments within himself/herself, with the individuals around him/her, and in the organization. Subsequently, a pool of items was created in accordance with the theoretical framework, a draft scale was obtained and a pilot study was conducted with 87 employees to determine the validity and reliability of this draft scale. In the analysis, a two-factor structure was obtained from the draft scale and it was found that this structure met the reliability and validity criteria. This factor structure was then tested on the main sample of 274 employees. All findings of the statistical analyses on the data obtained from the pilot study and the main sample showed that the developed scale had scientific validity and reliability and the scale was sufficient to be used in scientific researches.

Keywords: Organizational Improvement, Self-Expectation for Organizational Improvement, Positive Psychology Movement, Organizational Psychology, Scale Development

JEL Classification: D20, D23, M12

\section{ÖRGÜTSEL PSIKOLOJIDE YENI BİR YAKLASSIM: ORGANIZASYONEL IYYILEŞMEYE YÖNELIK ÖZ-BEKLENTİ VE BİR ÖLÇEK GELIŞTIRME ÇALIŞMASI}

Bu araştırmanın amacı örgütsel psikoloji alanına "Organizasyonel İyileşmeye Yönelik Öz-Beklenti” (OÏÖB) kavramını kazandırmak ve kavramın teorik-ampirik alt yapısını oluşturarak bir ölçüm aracı geliştirmektir. Araştırmada öncelikle OIÖB kavramına ilişkin teorik çerçeve oluşturulmuş ve Oİ̈̈B kavramı; organizasyon yönetiminin planlanmış eylemlerinden bağımsız olarak, bireyin tamamen kendi zihninde tasarladı̆̆ı; gelecekte bireyin kendisiyle, yakın çevresindeki bireylerle ve organizasyonla ilgili konularda olumlu yönde iyileşme ve gelişmeler yaşanacă̆ına ilişkin öz-beklentileri şeklinde tanımlanmıştır. Akabinde teorik çerçeveye uygun olarak bir madde havuzu oluşturulmuş, taslak bir ölçek elde edilmiş ve bu taslak ölçeğin geçerliliğini ve güvenilirliğini tespit edebilmek için 87 çalışan ile bir pilot çalışma yapılmıştır. Yapılan analizlerde taslak ölçekten iki faktörlü bir yapı elde edilmiş ve bu yapının güvenilirlik ve geçerlilik kriterlerini sağladığı tespit edilmiştir. Elde edilen bu faktör yapısı ise sonrasında 274 çalışanın katılım sağladı̆̆ esas örneklem üzerinde test edilmiştir. Pilot çalışmadan ve esas örneklemden elde edilen veriler üzerinde gerçekleştirilen istatistiksel analizlere ilişkin tüm bulgular, geliştirilen ölçeğin bilimsel geçerlilik ve güvenilirliğe sahip olduğunu ve ölçeğin bilimsel araştırmalarda kullanılabilecek yeterlilikte olduğunu göstermiştir.

Anahtar Kelimeler: Organizasyonel İyileşme, Organizasyonel İyileşmeye Yönelik Öz-Beklenti, Pozitif Psikoloji Hareketi, Örgütsel Psikoloji, Ölçek Geliştirme

JEL Kodlart: D20, D23, M12

\footnotetext{
${ }^{1}$ Assoc. Prof. Erzincan Binali Yıldırım University, Faculty of Economics and Administrative Sciences, mukaddes.yesilkaya@erzincan.edu.tr. https://orcid.org/0000-0002-6555-4659

${ }^{2}$ Assoc. Prof. Karamanoğlu Mehmetbey University, Faculty of Economics and Administrative Sciences, gokhankerse@ hotmail.com, https://orcid.org/0000-0002-1565-9110
} 


\section{INTRODUCTION}

From the earliest times when business organizations and professional management emerged, the most important focus of the organizations, both in theory and practice, has been to explore ways to increase the profit of the organization. The magic formula to reach this goal was expressed, firstly, as "productivity", then "human relations" and in the later periods as "relations with the external environment". Nowadays, it is not wrong to say that a formula that includes all of these and which can be shown as the "arkh $\vec{e}$ " of success in management is accepted as "human-centred strategic relations". This understanding, which places the people working in the organization, their talents, skills and features at the centre of the organizational activities, forms the basis of efforts to increase the profits of today's organizations.

An organization has to cope with the uncertainties and possible changes in the future in order to survive and continue their activities in an environment where market actors act with instant maneuvers, which are difficult to predict. However, uncertainty and change are difficult factors to control, not only in the external environment of the organization but also in the internal environment. Certainly, the structure of the organization, management style, culture, vision, goals, and strategies may change over time. However, it should be kept in mind that among the organizational elements, especially human resources is "the one with the highest tendency to change in the organization" and is most affected by the change. Because the human being is an entity who has some level of knowledge, wants to learn more; and they also change, heal and develop as they increase their knowledge. In particular, predicting the future and trying to manage it in its favour is the most important source of motivation that drives people to think and act strategically. Due to this propensity, people create their own expectations by combining present data and the information from their past experiences with signs about the future and they design the steps to be taken after such a process. With a more precise expression; it is evident that the real thing that builds one's own future is his / her expectations for the future and the steps he/she takes in relation to these expectations. That is why when people have positive expectations, they become more inclined to take constructive steps towards the future (e.g. self-improvement, progress, investment, taking risks, etc.) and when they have negative expectations, they are more inclined to take negative steps (e.g. pessimistic looking, abstaining, retreat, making mistakes). The basic logic here is also at the core of Vroom's Expectancy Theory. In other words, Vroom 
suggested that the higher the belief that a person will achieve that goal (valence) with the probability of success (expectation) perceived in achieving the goal, the more diligent the individual will be.

\section{THEORETICAL BACKGROUND OF THE CONCEPT OF SELF- EXPECTATION FOR ORGANIZATIONAL IMPROVEMENT (SEOI)}

As a result of the National Institute of Mental Health's funding for the diagnosis and treatment of mental illnesses after the Second World War; studies in the field of psychology have intensively focused on negative psychological characteristics such as biases, delusions, deficiencies and dysfunctions of human behaviour (Luthans, 2002). In recent years, however, a "positive psychology movement" has been initiated as a reaction to this focuses, led by renowned psychologist Martin Seligman. The "positive organizational behavior movement", which is an extension of this in organizations, has caused to spread in scientific studies an understanding that focuses on positive behaviors rather than negative behaviors (Seligman, 2002; Kutanis and Y1ld1z, 2014). Similarly, the concept of SEOI, which was proposed by this research for the first time and developed within the frame of positive psychology movement in terms of scope is a concept that aims to draw attention to the positive and strong aspects of the individual in the organization.

In essence, the concept of SEOI expresses the personal expectations of the individuals working in an organization that there will be improvements in a number of issues related to the organization. It is important to answer the question under which topics these issues should be expressed in structuring the epistemology of the SEOI concept. When seeking the answer to this question, it is possible to move on two axes of view in the management literature. The first is the "human-technical" classification based on the Tavistock Institute Research, which has made significant contributions to the formation of the "Human Relations Approach". The second is the "individual-group-organization" classification, which is generally accepted in the organizational behaviour literature and includes a more detailed distinction. It is possible to say that these two views move from the same point of origin, logically; the individual-group-organization classification is a more detailed explanation of the human-technical distinction. Therefore, the concept of SEOI can be defined in the broad sense as follows; independent of the planned actions of the organization management, self-expectations that the individual has designed completely in his/her own mind and that there will be positive improvements and developments within himself/herself, with the individuals around him/her, and in the 
organization. It is of great importance that the self-expectation here is fully self-developed after a certain process that can vary according to the individual without any conscious intervention of the organization management on the employees, in order to fully understand the concept. However, this concept should be considered as an output of a holistic process related to the past, present and future of the organization, more clearly, an internal opinion of a strategic nature.

On the other hand, the concept of SEOI is closely related to the individual's perceptions about the operations and treatment in the organization as well as the relationships carried out in the organization. Therefore, as in all other human characteristics, it is possible to say that the level of SEOI may vary from person to person, and may occur at different levels even in individuals working under the same conditions. Because each individual's personality, attitude, beliefs and perceptions, and perspective to events and facts are different from each other.

While constructing the conceptual framework of SEOI, use of its differences with other related concepts will be useful in terms of better understanding the concept and to clarify the conceptual boundaries. In the literature, no concept or research representing the self-expectations of employees towards improvement in organizational issues (in terms of individual, group and organization integrity) was found. However, although not directly related to the subject, there are two studies that can be considered indirectly related. In one of these studies (Portoghese et al., 2012), the effect of positive and negative expectations of employees on their commitment to change was investigated. It was found that employees with positive expectations were more willing to support change, but no theoretical or empirical information about "the content" of expectations for change was included in the study. However, when the theoretical framework of the research is taken into consideration, it is understood that the expectations of a "pre-planned" change are based on the management of the organization. Therefore, it can be said that the research in question is based on a set of managerial efforts, which were created consciously and purposefully by "the intervention of the organization's management" and aimed at meeting the change completely.

In the other study (Sutton and Griffin, 2004), the effect of the expectations related to the three areas (payment, supervision and content of the job before employment and job satisfaction after the employment) was discussed. In this context, in the relevant research, the measurements were based on the experience-oriented knowledge rather than the 
expectations of the employees. However, the concept of SEOI is based not only on the past but also on a much more comprehensive perspective that focuses on the present and the future.

On the other hand, although the concept of SEOI, firstly proposed in this study, seems to be similar to the various concepts discussed in different disciplines such as the concepts of "positive change expectation", "positive expectations towards future" and "positive psychological capital"; it has a very different structure in terms of its resources, cause-effect relationships and conceptual framework it has.

The concept of "positive change expectation", one of the aforementioned concepts, is mainly examined in the medical and health science literature (Avitia, 2014; Tschacher, 2014; Zarbo vd., 2016; Hoyer and Baum, 2008; Gürsel, 2012; Klump and Butcher, 1997). Besides, in a study dealing with organisational culture, it was seen that this concept was only included in the sentence (Froese et al. 2008).

A similar situation applies to the concepts of "positive expectations towards future" or "positive future expectation". It is seen that this concept has been used in different research areas and conceptually in a totally different contexts such as the degree of positiveness of the individual's expectations about his / her own personal future (Callina et al. 2014; Eryllmaz, 2011; Schmid et al., 2011; Zhou and Lu, 2011), positive expectations about the future firm competitions (Hansen, 2003) or the positive impact of the project team on obtaining information (Hamersma et al., 2016). The literature review and their results revealed that these two concepts (at least in the sources that are put forward and used) are used only superficially without any definition; in other words, they do not have a conceptual framework and a systematized theoretical infrastructure.

The concept of "positive psychological capital" refers to the psychological capacity of the individual in terms of work motivation, a positive mood that must be maintained and developed by the organization management (Luthans et al., 2004; Avey et al., 2008; Avey et al., 2011; Smith et al., 2009; Luthans and Youssef, 2004). When the theoretical and empirical structure is examined in these studies, it was seen that the concept is expressed in a four-dimensional concept in the form of self-efficacy, hope, optimism and flexibility. Although the dimensions of hope and optimism are similar to those of the SEOI, considering the content of these dimensions, it is seen that the concept is structured within the framework of a perspective that includes only an individual's hope and optimism about his own goals. However, the concept of SEOI uses a much broader approach including not 
only the individual's expectations of himself/herself but also the expectations of other elements around him/her (group, management style, methods of doing business and the whole organization).

When all of the above issues are taken into consideration as a whole, it is possible to say that the concept proposed in this study presents a new and different perspective to the literature. As a matter of fact, the concept of SEOI presents a brand new composition including four important issues in the literature that other researches dealing with similar concepts do not have. It is possible to summarize these points as follows:

1. Holistic perspective: Contrary to similar concepts in the literature, the concept of SEOI contains not only the individual's own future but also the expectations of improvements and progress that will be experienced in the future in the context of "individual-group-organization interaction". From this holistic perspective, SEOI departs from other similar studies in the literature (Avey et al., 2008; Avey et al., 2011; Smith et al., 2009; Luthans et al., 2004; Luthans and Youssef, 2004; Sutton and Griffin, 2004; Callina et al. 2014; Eryılmaz, 2011; Schmid et al., 2011; Zhou and $\mathrm{Lu}, 2011)$.

2. Content of expectations: In a very important part of the relevant literature, no details were given about what content is related to the expectations of the individual (Portoghese et al., 2012; Froese et al. 2008; Luthans et al., 2004; Avey et al., 2008; Avey et al., 2011; Smith et al., 2009; Luthans and Youssef, 2004; Avitia, 2014; Tschacher, 2014; Zarbo et al., 2016; Hoyer and Baum, 2008; Gürsel, 2012; Klump and Butcher, 1997; Luthans et al. 2004; Avey et al., 2008; Avey et al., 2011; Smith et al., 2009; Luthans and Youssef, 2004). However, the concept of SEOI has different and a broad content on many issues such as the individual him/herself, as well as from manager to colleagues, from technology to corporate activities.

3. Spontaneous formation: In some of the studies in the literature on similar concepts, it is noteworthy that organizational management interferes with the expectations of individuals consciously (Portoghese et al., 2012; Hamersma et al., 2016). However, SEOI represents the expectations that totally occur spontaneously in the mind of the individual without any conscious and planned intervention by the organization management, and their hopes on certain issues regarding the future.

4. Being strategic nature: Since the concept of SEOI includes a combination of both past, present, and future, it should be seen as an inner source of energy that has a 
significant determinant in employees' thoughts, decisions and behaviors. In this respect, SEOI should be evaluated as a potential feature to constitute a kind of weight point, especially in strategic human resources management.

In the continuation of the study, starting from the theoretical framework explained above; a measurement material has been developed in order to determine the positive selfexpectation that the individual will have improvements in human and institutional issues related to the organization he/she works for. The development stages of the scale are detailed below.

\section{EMPIRICAL STRUCTURE OF SEOI CONCEPT}

The SEOI scale was developed based on the criteria of Hinkin (1995). According to Hinkin (1995), this process consists of (1) establishing the pool of items, (2) structuring the scale and (3) evaluating.

\section{a. Step 1: Establishing the Pool of Items}

Since the study was aimed to develop an original scale, it has been started from the theoretical background for the concept of SEOI. Therefore, while the item pool was formed, the item pool was based on the generally accepted "individual-group-organization" distinction in the organizational behaviour literature as it contains a more detailed classification than the "human-technical" classification used in the Tavistock Institute Research and thus a total of 16 items were created under three main components: "expectations about him/herself (6)", "expectations about individuals in the immediate vicinity (5)" and "expectations about improvements in organizational matters (5)".

\section{b. Step 2: Structuring the Scale}

At this stage, the content and structure validity of the item pool which consisted of 16 statements were tried to be ensured. For content validity, the items were submitted to the opinion of 8 experts in the related field. The experts assessed both the clarity and suitability of the substances. Experts were asked to give scale items between 1 and 5 points for clarity and suitability $(1=$ Not at all understandable, incompatible; $5=$ Completely understandable, compliant). Giving 4 and 5 points to the items indicated the suitability of the item while giving 1, 2 and 3 points showed that it was not appropriate. Expert forms were evaluated with reference to Lawshe's Scope Validity Ratio (Künter and Gürbüz, 
2014). In the case of 8 experts, the minimum scope validity ratio value should be 0,75 (Çınar and Basım, 2018). In this direction, necessary calculations were made for each item with the formula of Lawshe (1975) and 2 items below 0,75 were excluded from the scale. Therefore, the content validity of the 14-item questionnaire (self-expectation for improvement in human subjects - 9 items and self-expectation for improvement in organizational issues - 5 items $)$ was provided and a 5-point Likert Type $(1=$ Strongly Disagree; 5 = Strongly Agree) was prepared.

A pilot study was conducted in the health sector for the structuring of the 14-item draft questionnaire, in other words, for constructing the validity. In order to perform factor analysis in the pilot study, it is considered the data obtained should be at least 50 (Hair et al. 2014) and the number of items in the scale should be 5 times (Büyüköztürk, 2002) and data were collected from 87 nurses on a voluntary basis by convenience sampling method. When the 87 pilot study participants were examined, it was seen that the ratio of those less than 30 years old was the highest $(39,0 \%)$ and the ratio of those over 51 years old was the lowest $(3,4 \%)$. On the other hand, in terms of experience, the rate of participants working for 10 years or less is $41,4 \%$. Additionally, it was determined that the ratio of those at the undergraduate level was highest $(66,7 \%)$ in terms of education level.

The data obtained from the pilot participants were subjected to exploratory factor analysis with SPSS 18.0 package program for construct validity. The principal component method and varimax rotation technique were used for factor analysis. In the analysis, the following two tests were taken as reference, indicating that the data were suitable for factor analysis and significant factors would be obtained: The Kaiser-Mayer-Olkin (KMO) value was higher than 0,60 and the Barlett Sphericity test value was $<0,05$ (Leech et al. 2005). In addition, it is expected to be the factor load values of 0,40 and above (Field, 2009) and the desired variance ratio of above $50 \%$ in the overall scale (Yaşlığlu, 2017). No size limitation was applied during the analysis. In the analysis, the scree plot was taken into consideration and the eigenvalue of the dimensions above 1 was taken as reference (Tabachnick and Fidell 2007). Findings of exploratory factor analysis are presented in Table 1. 
Table 1. Pilot Study: Exploratory Factor Analysis Findings

\begin{tabular}{|c|c|c|c|c|}
\hline Factors & $\begin{array}{l}\text { Factor } \\
\text { Loads }\end{array}$ & Eigenvalues & $\begin{array}{l}\text { Explained } \\
\text { Variance }\end{array}$ & $\begin{array}{l}\text { Total } \\
\text { Variance }\end{array}$ \\
\hline $\begin{array}{l}\text { Factor 1: Self-Expectation for Improvement In } \\
\text { Human Subjects }\end{array}$ & & 5,776 & 41,258 & 41,258 \\
\hline $\begin{array}{l}\text { SEOI3. I believe that I will do my work better as } \\
\text { time goes on. }\end{array}$ & 871 & & & \\
\hline $\begin{array}{l}\text { SEOI9. I believe that the contribution of the unit } \\
\text { I work for will increase in the future. }\end{array}$ & ,848 & & & \\
\hline $\begin{array}{l}\text { SEOI2. I think my relationship with other people } \\
\text { working in the unit I'm working with will be } \\
\text { better gradually. }\end{array}$ & ,844 & & & \\
\hline $\begin{array}{l}\text { SEOI7. Together with my colleagues, we love } \\
\text { discovering new ways and methods of doing } \\
\text { business and teaching them to each other. }\end{array}$ & ,806 & & & \\
\hline $\begin{array}{l}\text { SEOI8. I believe that the cooperation and } \\
\text { solidarity in my unit will increase gradually. }\end{array}$ & ,770 & & & \\
\hline $\begin{array}{l}\text { SEOI6. I think that the relations of the people in } \\
\text { the unit I work with will be better in the future. }\end{array}$ & ,733 & & & \\
\hline $\begin{array}{l}\text { SEOI5. I believe that I will be able to solve future } \\
\text { problems related to my work. }\end{array}$ & ,724 & & & \\
\hline $\begin{array}{l}\text { SEOI4. In the future, I believe I will work in a } \\
\text { higher status than the one I am currently working } \\
\text { for. }\end{array}$ & ,591 & & & \\
\hline $\begin{array}{l}\text { SEOI1. I believe that my relations with the } \\
\text { manager of the unit I am affiliated with will } \\
\text { strengthen in the future. }\end{array}$ & ,545 & & & \\
\hline $\begin{array}{l}\text { Factor 2: Self-Expectation for Improvement } \\
\text { in Organizational Issues }\end{array}$ & & 5,154 & 36,812 & 78,071 \\
\hline $\begin{array}{l}\text { SEOI13. I believe that the institution I work for } \\
\text { will produce more successful jobs in the future. }\end{array}$ & ,907 & & & \\
\hline $\begin{array}{l}\text { SEOI12. I believe that the current structure and } \\
\text { functioning of the institution I work for will be } \\
\text { more effective and efficient in the future. }\end{array}$ & ,902 & & & \\
\hline $\begin{array}{l}\text { SEOI11. I think that instead of the current } \\
\text { methods of doing business in my institution, there } \\
\text { will be new and much more useful methods that } \\
\text { will minimize the problems in the future. }\end{array}$ & ,868 & & & \\
\hline $\begin{array}{l}\text { SEOI14. As an employee of this organization, I } \\
\text { believe that everything will be much better in the } \\
\text { future. }\end{array}$ & ,845 & & & \\
\hline $\begin{array}{l}\text { SEOI10. I can see that the general management } \\
\text { style of the institution I work for has improved } \\
\text { and will continue in the future. }\end{array}$ & ,820 & & & \\
\hline $\mathrm{KMO}=, 927$ & Bartlett & tericity Test $=$ & 417,617 & $\mathrm{P}=, 000$ \\
\hline
\end{tabular}

When the findings in Table 1 are considered, it is seen that KMO $(0,927)$ and Bartlett Sphericity test $(0,000)$ values provide reference criteria. In the analysis, it was observed that the scale items exhibited a 2 -factor structure. When the item pool was created, it was stated that the "individual-group-organization" classification was preferred for the scale because it included a more detailed distinction. Therefore, it is not surprising that the scale exhibits a two-factor 
decomposition of the "human-technical" classification after the pilot study, as stated in the theoretical background. Thus, the first factor obtained was named as "self-expectation for improvement in human subjects" while the second factor was called "self-expectation for improvement in organizational issues". The analysis findings in Table 1 showed that each of the factors' eigenvalues $(5,776$ and 5,154$)$ met the criterion-referenced. The scale explained $78,071 \%$ of the total variance. When the factor load value of the item was examined, no material with a value below 0,40 was found. The scree plot obtained from the exploratory factor analysis of the scale is given in Figure 1.

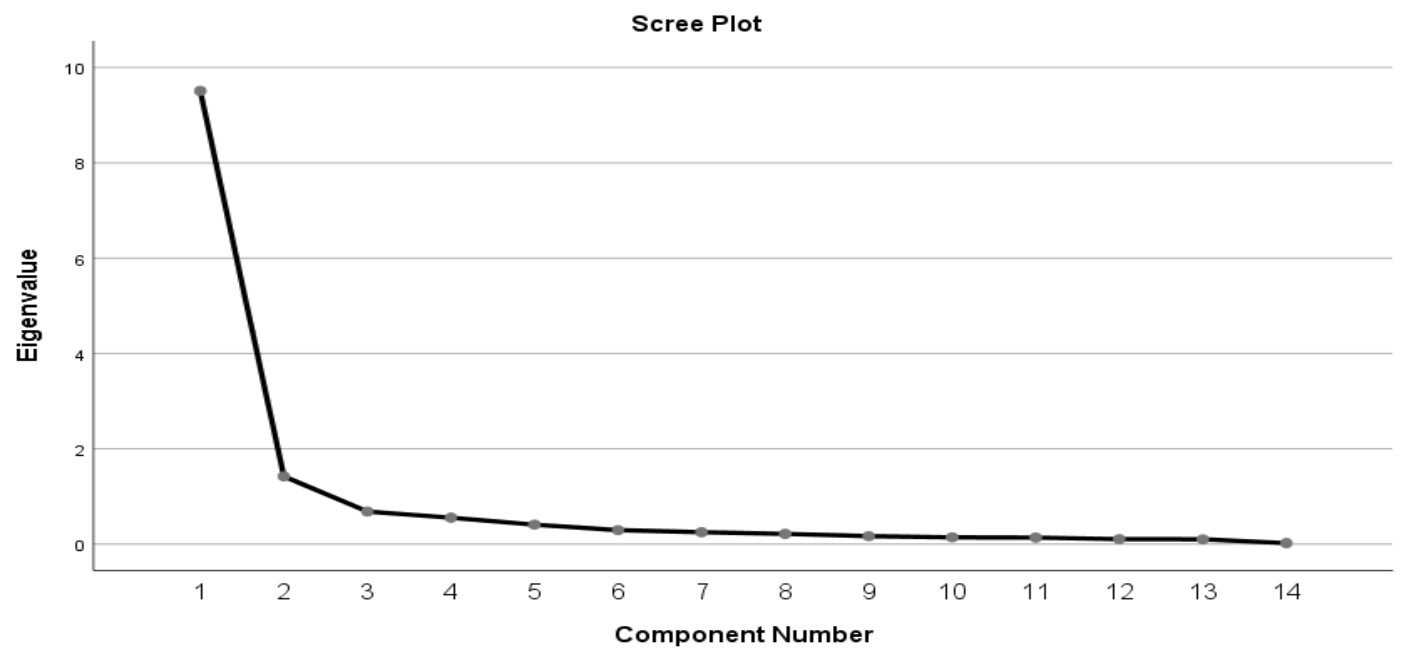

Figure 1. Pilot Study: Scree Plot Chart

The graph in Figure 1 provided the opportunity to evaluate the number of factors obtained from a different perspective. When the graph is examined, it is seen that the curve starts to flatten at the second point; therefore, it is seen that the factors obtained after this point will not affect the variance significantly.

For the two-factor structure obtained by exploratory factor analysis, the reliability of each factor and overall scale were also examined. Cronbach's alpha coefficient, which shows internal consistency, was examined for reliability. Higher than 0,70 of Cronbach Alpha value was taken as a reference (Field, 2009). In the analyses, the Cronbach Alpha coefficient of the self-expectation factor for improvement in organizational issues was 0,968 while the selfexpectation factor for improvement in human subjects was found to be 0,945 and the Cronbach's alpha coefficient for the overall scale was 0,962 ; thus providing the reference criterion.

\section{c. Step 3: Evaluating The Scale}

The 14-item scale, which was obtained in the previous stage and was pre-accepted by the pilot study, was evaluated on the main sample. The main sample also included the health 
sector employees and it was found that 261 employees out of 812 employees provide a $95 \%$ confidence level (https://www.surveysystem.com/sscalc.htm). Data were collected on a voluntary basis from 274 employees by easy sampling method. It has been identified that among the demographic characteristics of the participants, 25 were doctors, 74 were nurses, 48 were health workers, 25 were technical staff, 19 were administrative staff and 83 were employees in the other group. According to the findings, the majority of the group was under the age of 30 $(41,6 \%)$. This group was followed by the groups between 31-40 years (32,5\%), 41-50 years $(21,2 \%)$ and over 51 years $(4,7 \%)$. In addition, the findings showed that the majority of participants are working for 10 years or less $(50,7 \%)$. In terms of education variable, individuals with undergraduate degrees $(39,4 \%)$ had the highest rates and individuals with a Ph.D. degree $(2,9 \%)$ represented the lowest rates.

The data obtained were analysed by exploratory and confirmatory factor analysis, respectively. Firstly, the factor structure of the 14-item scale was determined by exploratory factor analysis on the main sample. There was no restriction on the number of factors in exploratory factor analysis. The findings are presented in Table 2.

The findings in Table 2 indicate that the KMO value $(0,949)$ is sufficient for the sample of the analysis, and the Barlett Sphericity test value $(0,000)$ showed that significant factors are obtained from the analysis. On the other hand, a factor structure equivalent to the factor structure obtained in the pilot study was obtained and item factor loads of each dimension provided a reference value of 0,40 . The first factor was named as "self-expectation for improvement in human subjects" and the second as "self-expectation for improvement in organizational issues". The eigenvalues of the factors were above $1(5,618$ and 5,092) and the scale explained $76,497 \%$ of the total variance. 
Table 2. Main Sample: Exploratory Factor Analysis Findings

\begin{tabular}{|c|c|c|c|c|}
\hline Factors & $\begin{array}{l}\text { Factor } \\
\text { Loads }\end{array}$ & Eigenvalues & $\begin{array}{l}\text { Explained } \\
\text { Variance }\end{array}$ & $\begin{array}{l}\text { Total } \\
\text { Variance }\end{array}$ \\
\hline $\begin{array}{l}\text { Factor 1: Self-Expectation for Improvement In } \\
\text { Human Subjects }\end{array}$ & & 5,618 & 40,126 & 40,126 \\
\hline $\begin{array}{l}\text { SEOI2. I think my relationship with other people } \\
\text { working in the unit I'm working with will be } \\
\text { better gradually. }\end{array}$ &, 841 & & & \\
\hline $\begin{array}{l}\text { SEOI3. I believe that I will do my work better as } \\
\text { time goes on. }\end{array}$ &, 831 & & & \\
\hline $\begin{array}{l}\text { SEOI7. Together with my colleagues, we love } \\
\text { discovering new ways and methods of doing } \\
\text { business and teaching them to each other. }\end{array}$ &, 814 & & & \\
\hline $\begin{array}{l}\text { SEOI5. I believe that I will be able to solve } \\
\text { future problems related to my work. }\end{array}$ & ,790 & & & \\
\hline $\begin{array}{l}\text { SEOI8. I believe that the cooperation and } \\
\text { solidarity in my unit will increase gradually. }\end{array}$ &, 772 & & & \\
\hline $\begin{array}{l}\text { SEOI6. I think that the relations of the people in } \\
\text { the unit I work with will be better in the future. }\end{array}$ & ,729 & & & \\
\hline $\begin{array}{l}\text { SEOI9. I believe that the contribution of the unit } \\
\text { I work for will increase in the future. }\end{array}$ & ,683 & & & \\
\hline $\begin{array}{l}\text { SEOI4. In the future, I believe I will work in a } \\
\text { higher status than the one I am currently } \\
\text { working for. }\end{array}$ & ,625 & & & \\
\hline $\begin{array}{l}\text { SEOI1. I believe that my relations with the } \\
\text { manager of the unit I am affiliated with will } \\
\text { strengthen in the future. }\end{array}$ &, 584 & & & \\
\hline $\begin{array}{l}\text { Factor 2: Self-Expectation for Improvement in } \\
\text { Organizational Issues }\end{array}$ & & 5,092 & 36,371 & 76,497 \\
\hline $\begin{array}{l}\text { SEOI12. I believe that the current structure and } \\
\text { functioning of the institution I work for will be } \\
\text { more effective and efficient in the future. }\end{array}$ & ,905 & & & \\
\hline $\begin{array}{l}\text { SEOI13. I believe that the institution I work for } \\
\text { will produce more successful jobs in the future. }\end{array}$ & ,892 & & & \\
\hline $\begin{array}{l}\text { SEOI11. I think that instead of the current } \\
\text { methods of doing business in my institution, there } \\
\text { will be new and much more useful methods that } \\
\text { will minimize the problems in the future. }\end{array}$ &, 862 & & & \\
\hline $\begin{array}{l}\text { SEOI14. As an employee of this organization, I } \\
\text { believe that everything will be much better in the } \\
\text { future. }\end{array}$ & ,838 & & & \\
\hline $\begin{array}{l}\text { SEOI10. I can see that the general management } \\
\text { style of the institution I work for has improved } \\
\text { and will continue in the future. }\end{array}$ &, 831 & & & \\
\hline KMO $=, 949$ & Bartle & phericity Test & $\overline{4144,047}$ & $\bar{p}=, 000$ \\
\hline
\end{tabular}

After the exploratory factor analyses conducted on both the pilot study and the data obtained from the main sample, it became clear that the SEOI scale was valid with a 2-factor structure. At this point, it is possible to define the factors that make up the scale structure as follows:

- $\quad$ Self-expectation for improvement in human subjects: It includes self-expectations of individuals for his/her work, status and relations with the manager, and also 
improvements concerning other individuals in their immediate surroundings and their relationships with each other, cooperation and solidarity and their contribution to the organization together.

- Self-expectation for improvement in organizational issues: It expresses the selfexpectations of the individual concerning the general structure, functioning and management style of her/his organization, the methods of doing business used in the organization and corporate success.

In the main sample, the accuracy of the factor structure obtained by exploratory factor analysis was tested by confirmatory factor analysis. Maximum Likelihood technique was used in the confirmatory factor analysis and the standardized regression load (item factor load) of 0,50 and above was taken as a reference. The model obtained as a result of the analysis is presented in Figure 2.

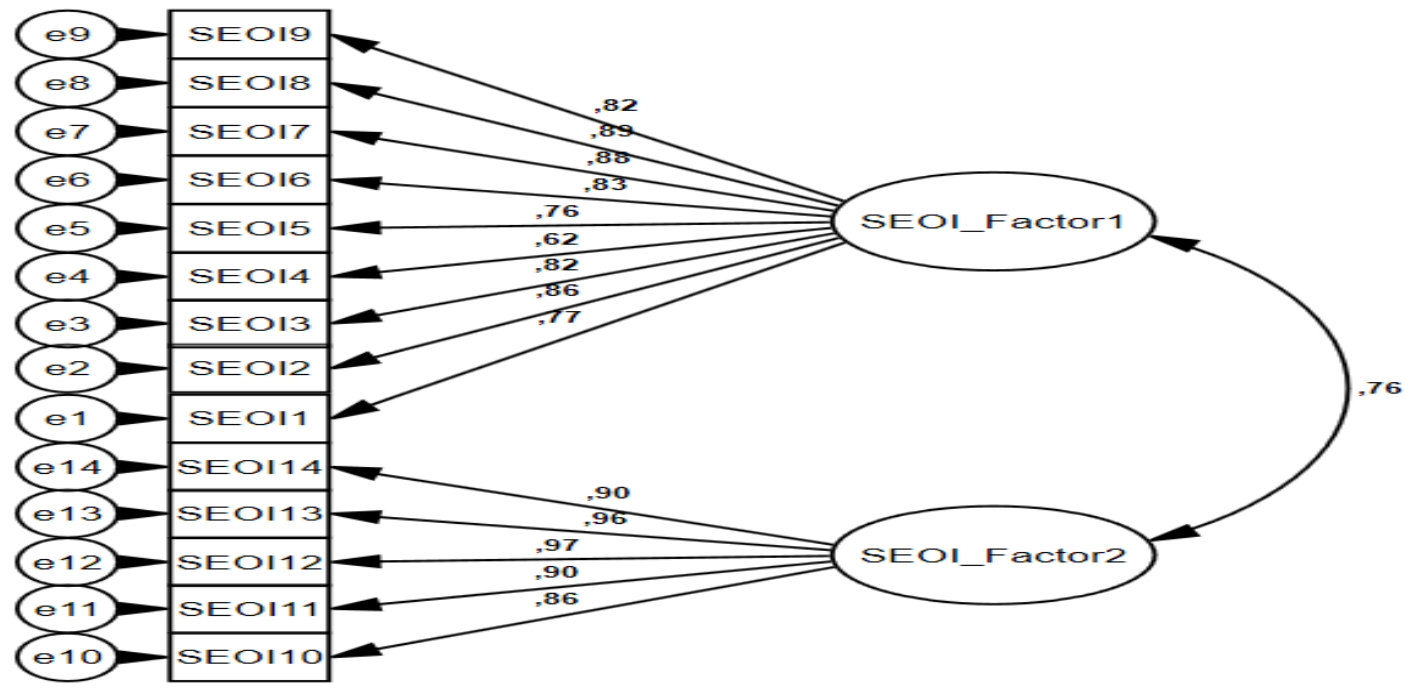

Figure 2. Confirmatory Factor Analysis before Modification

When the model in Figure 2 is examined, it is seen that item factor loads are above the referenced value of 0,50 . Goodness of fit of the model is given in Table 3 .

Table 3. Pre-modification Goodness of Fit Values

\begin{tabular}{lll}
\hline Indexes & Reference Value & Measurement Model \\
\hline CMIN/DF & $0<\chi 2 / \mathrm{sd} \leq 5$ & 4,405 \\
\hline RMR & $\leq, 10$ &, 063 \\
\hline GFI & $\geq, 90$ &, 849 \\
\hline CFI & $\geq, 90$ &, 937 \\
\hline IFI & $\geq, 90$ &, 938 \\
\hline TLI & $\geq, 90$ &, 925 \\
\hline NFI & $\geq, 90$ &, 921 \\
\hline RMSEA & $<, 05-\leq, 08$ &, 112 \\
\hline
\end{tabular}


It is seen that the model goodness values given in Table 3 do not provide reference values. This means that the present situation does not have an acceptable fit. As a result of the investigation, it was determined that the goodness of fit values would be improved with the modifications made among some substances. Therefore, modifications were made between SEOI 1 and SEOI 2, SEOI 2 and SEOI 3, SEOI 3 and SEOI 5, SEOI 6 and SEOI 9, and SEOI 7 and SEOI 9. The factor structure model obtained after the modification is presented in Figure 3.

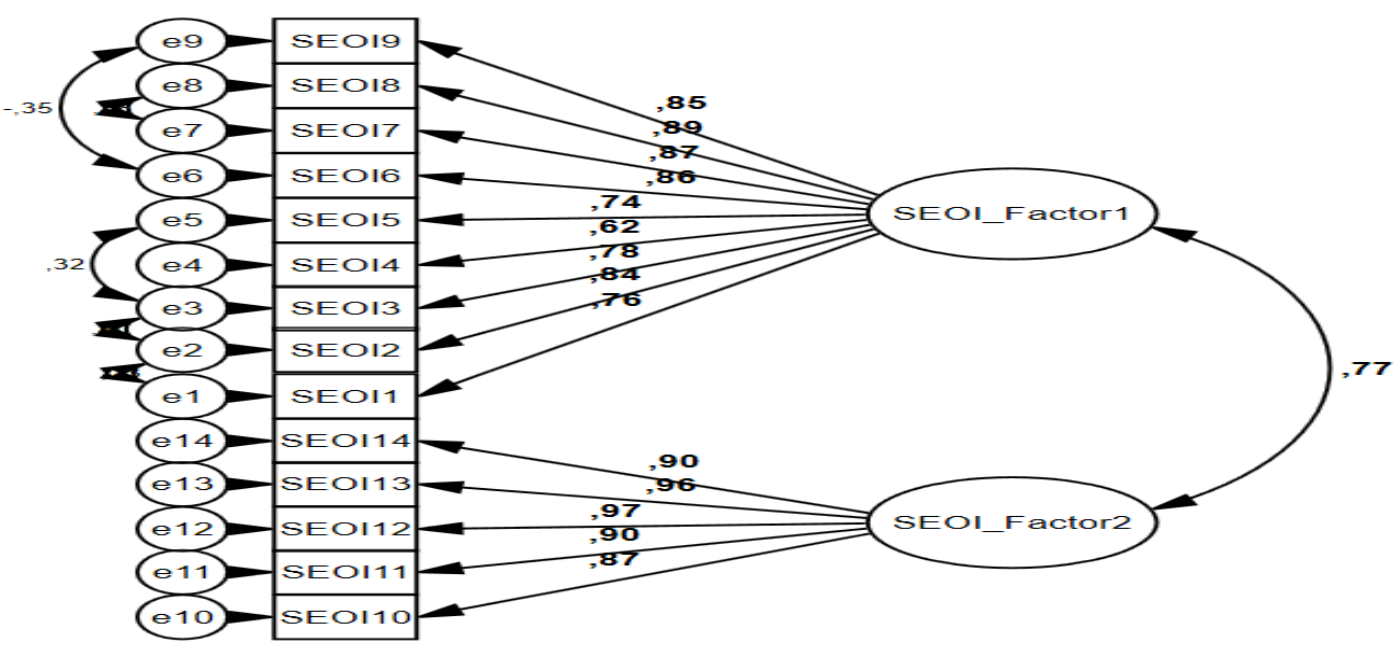

Figure 3. Post-modification Confirmatory Factor Analysis

The goodness of fit of the model obtained after the modification of the model is presented in Table 4.

Table 4. Goodness of Fit after Modification

\begin{tabular}{lll}
\hline Indexes & Reference Value & Measurement Model \\
\hline CMIN/DF & $0<\chi^{2 / \mathrm{sd} \leq 5}$ & 2,664 \\
\hline RMR & $\leq, 10$ &, 053 \\
\hline GFI & $\geq, 90$ &, 913 \\
\hline CFI & $\geq, 90$ &, 971 \\
\hline IFI & $\geq, 90$ &, 972 \\
\hline TLI & $\geq, 90$ &, 963 \\
\hline NFI & $\geq, 90$ &, 955 \\
\hline RMSEA & $<, 05-\leq, 08$ &, 078 \\
\hline
\end{tabular}

The goodness of fit values in Table 4 indicates that the goodness of fit of the model created with the two-factor structure is acceptable; therefore, the model obtained by exploratory factor analysis is validated.

In the study, the reliability analysis of the scale was repeated with the data obtained from the main sample. Internal consistency in reliability and Cronbach alpha coefficients were examined in this direction. The findings revealed that the "self-expectation for improvement in 
human subjects" dimension was 0,941 and the "self-expectation for improvement in organizational issues" dimension was 0,964 while the overall scale has a value of 0,960 Cronbach alpha. In addition, it was observed that there was no significant increase in Cronbach alpha coefficient if any of the scale items were deleted.

CR (composite reliability) and AVE (average variance added) values were also calculated for the reliability and validity of the scale. Among these values, CR values higher than 0,70 and AVE is higher than 0,50 are taken as reference (Hair et al., 1995). As a result of the analyses and calculations, it was obtained that the AVE (self-expectation for improvement in human issues $=0,644$; self-expectation for improvement in organizational issues $=0,848$ ) and CR (self-expectation for improvement in human issues $=0,941$; self-expectation for improvement in organizational issues $=0,965$ ) values of the two-factor structure meet the reference values.

Finally, the correlations between items showing internal consistency reliability were also examined. The findings obtained in the analysis are presented in Table 5.

Table 5. Item Correlation Findings

\begin{tabular}{|c|c|c|c|c|c|c|c|c|c|c|c|c|c|c|}
\hline Item & 1 & 2 & 3 & 4 & 5 & 6 & 7 & 8 & 9 & 10 & 11 & 12 & 13 & 14 \\
\hline SEOI1 & 1 & & & & & & & & & & & & & \\
\hline SEOI2 &, $734^{* *}$ & 1 & & & & & & & & & & & & \\
\hline SEOI3 &, $631^{* *}$ &, $808^{* *}$ & 1 & & & & & & & & & & & \\
\hline SEOI4 &, $441^{* * *}$ &, $516^{* *}$ &, $550^{* *}$ & 1 & & & & & & & & & & \\
\hline SEOI5 &, $526^{* *}$ &, $671^{* *}$ &, $737^{* *}$ &, $522^{* *}$ & 1 & & & & & & & & & \\
\hline SEOI6 & ,611** &, $703^{* *}$ &, $602^{* *}$ &, $502^{* *}$ & ,639" & 1 & & & & & & & & \\
\hline SEOI7 &, $633^{* *}$ &, $728^{* *}$ & ,692 &, $554^{* *}$ & ,658 &, $779^{* *}$ & 1 & & & & & & & \\
\hline SEOI8 &, $644^{* *}$ &, $739^{* *}$ & ,669 &, $538^{* *}$ & ,629 &, $791^{* *}$ &, $856^{* *}$ & 1 & & & & & & \\
\hline SEOI9 &, $662^{* *}$ &, $709^{* *}$ & ,695 &, $518^{* *}$ &, $609^{* * *}$ &, $634^{* *}$ &, $704^{* *}$ &, $741^{* *}$ & 1 & & & & & \\
\hline SEOI10 & ,658 &, $522^{* *}$ &, $511^{* *}$ &, $471^{* *}$ &, $475^{* *}$ &, $597^{* *}$ &, $604^{* *}$ & ,638 & ,677 & 1 & & & & \\
\hline SEOI1 1 & ,646 &, $546^{* *}$ &, $535^{* *}$ &, $424^{* *}$ &, $489^{* * *}$ &, $585^{* *}$ &, $575^{* *}$ &, $624^{* *}$ &, $647^{* *}$ &, $805^{* *}$ & 1 & & & \\
\hline SEOI12 & ,684* &, $563^{* *}$ &, $536^{* *}$ &, $471^{* *}$ &, $521^{* *}$ &, $624^{* *}$ & ,600 &, $653^{* *}$ & ,670 &, $848^{* *}$ &, $879^{* *}$ & 1 & & \\
\hline SEOI13 & ,664 &, $572^{* *}$ &, $551^{* *}$ &, $452^{* *}$ &, $524^{* *}$ &, $617^{* *}$ &, $584^{* *}$ & ,637** & ,645 &, $812^{* * *}$ &, $862^{* *}$ &, $933^{* *}$ & 1 & \\
\hline SEOI14 & ,642** &, $566^{* *}$ &, $553^{* *}$ &, $490^{* *}$ &, $497^{* *}$ &, $616^{* *}$ &, $577^{* *}$ &, $633^{* *}$ &, $633^{* *}$ &, $757^{* *}$ &, $783^{* *}$ &, $876^{* *}$ &, $884^{* *}$ & 1 \\
\hline
\end{tabular}


When the correlation findings in the table are examined, it is seen that each item is positively correlated with the other scale items at a 99\% significance level. This means that the scale items are consistent among themselves; that is, internal consistency is achieved. Therefore, all findings showed that the 14-item scale (Appendix 1) was reliable.

\section{CONCLUSION AND SUGGESTIONS}

With postmodernist understanding spreading to the field of organizational behaviour or organizational psychology as well as almost all other fields, the negative understanding of psychology, which previously focused on the negative and problematic aspects of employees, is now being replaced rapidly by the concept of "positive psychology", which focuses on the positive and strong characteristics of employees. In line with this evolution, it is possible to say that researchers are also concentrating on discovering new positive characteristics of employees. In this research, a brand new feature that can be shown as one of the positive characteristics of individuals working in organizations has been discussed, the theoreticalempirical background of the concept representing this feature has been established and the concept has been introduced to the literature. This feature, which we conceptualize as SelfExpectation for Organizational Improvement, is generally attributed to: The individuals' expectations that are structured in their own minds within a certain process independently of the planned actions of the organization management and that there will be positive human and institutional improvements and developments in the organization they work. These expectations are developed according to the individual's own perception, therefore they are personal, comprehensive and strategic. In addition, these expectations give an idea about the individual's perspective on human and institutional issues.

On the other hand, a measurement material was developed in accordance with the theoretical framework established in this study. A three-step process was followed in the development of the scale. First of all, a pool of items was created by considering the conceptual framework. Then, content validity was obtained with the findings of expert opinions and a pilot study was conducted to test the construct validity. For construct validity, exploratory factor analysis was performed and both factor load values and Kaiser-Mayer-Olkin (KMO) and Barlett Sphericity test values met the reference criteria. In the analysis, a two-factor structure was obtained, namely "self-expectation for improvement in human subjects" and "self-expectation for improvement in organizational issues" and it was concluded that the structure was quite significant with the scree plot. The reliability analyses of the scale were made and it was determined that both the overall scale and the dimensions were reliable based on the Cronbach 
alpha coefficient values. Therefore, the preliminary acceptance of the 14-item scale was achieved. Finally, the preliminary acceptance of the scale was evaluated in the main sample. The main sample consisted of 274 health sector workers. Exploratory and confirmatory factor analyzes were applied to the data obtained from the sample, respectively. Thus, it was examined whether the factor structure obtained by the pilot study was supported. Findings of exploratory factor analysis were in parallel with the findings of the pilot study and the same two-factor structure was obtained. By fulfilling all the criteria taken as a reference, the factor structure was verified by confirmatory factor analysis. In the confirmatory factor analysis, inter-item modifications were made and in this case, the structure obtained by exploratory factor analysis was found to be acceptable. The reliability of the scale was also tested with the data obtained from the main sample and it was determined that the scale as a whole, as well as the dimensions, were reliable.

When all the findings were evaluated as a whole, it was concluded that the selfexpectation scale for organizational improvement was a reliable and valid scale in organizational behaviour literature. With the help of this scale, it can be possible to determine the level of the feature related to the concept and whether it affects the individual's attitudes and behaviours, decisions and plans for the future in the workplace, and if so, at what level. Therefore, it is hoped that this study will contribute to both national and international literature as it provides both a theoretical background on Self-Expectation for Organizational Improvement and a reliable and valid scale for determining this feature.

On the other hand, the study has some limitations. One of the limitations is to ensure the preliminary acceptance of the item pool created in the study with a limited number of samples and this pilot sample and the main sample are selected from the same sector. The second limitation is the cross-sectional collection of data and the possibility of finding common method variance. Taking these constraints into consideration, testing the scale in relation to different variables in different sectors and examining the possible variables in the field may be a guide for future research likewise.

In addition to the above suggestions, the concept of SEOI represents an inner energy source, for individuals that working at all levels of the organization. Correspondingly the concept draws attention to an important potential that can directly affect the willingness to working of individuals in the organization and their working outputs. For future research, theoretical and empirical studies on how this feature should be maintained and strengthened by organizational management may be proposed. Moreover, the concept of SEOI creates a wide- 
range of study area that can be associated with an unlimited number of variables such as organizational commitment, organizational culture, job satisfaction, innovation, creativity, organizational identity, and organizational citizenship, as well as can be linked to many postmodernist management practices such as total quality management, psychological empowerment, leadership and so on. 


\section{REFERENCES}

Avey, J., Wernsing, T. S. and Luthans, F., (2008), “Can Positive Employees Help Positive Organizational Change? Impact of Psychological Capital and Emotions on Relevant Attitudes and Behaviors", The Journal of Applied Behavioral Science, 44(1), 48-70.

Avey, J. B., Reichard, R. J., Luthans, F. and Mhatre, K. H., (2011), "Meta-Analysis of The Impact of Positive Psychological Capital on Employee Attitudes, Behaviors, and Performance", Human Resource Development Quarterly, 22(2), 127-152.

Avitia, A.C.A., (2014), Expectations Regarding Psychotherapy and Therapeutic Alliance in Women with Depression: A Study in Two Different Cultural Contexts, Unpublished Doctoral Thesis, Faculty of Behavioral and Cultural Studies, Heidelberg University in Cooperation with Pontificia Universidad Católica de Chile.

Büyüköztürk, Ş., (2002), "Faktör Analizi: Temel Kavramlar ve Ölçek Geliştirmede Kullanımı”, Kuram ve Uygulamada Ĕ̌itim Yönetimi, 32, 470-483.

Callina, K. S., Johnson, S. K., Buckingam, M. H. and Lerner, R. M., (2014), "Hope in Context: Developmental Profiles of Trust, Hopeful Future Expectations, and Civic Engagement Across Adolescence", Journal of Youth and Adolescence, 43, 869-883.

Çınar, E. and Basım, H.N. (2018). "Sosyal Rol Kimliği: Bir Ölçek Geliştirme Çalışması”, International Social Sciences Studies Journal, 4(28): 6492-6498

Eryılmaz, A., (2011), "Ergen Öznel İyi Oluşu İle Olumlu Gelecek Beklentisi Arasındaki İlişkinin İncelenmesi”, Düşünen Adam Psikiyatri ve Nörolojik Bilimler Dergisi, 24, 209-215.

Field, A., (2009), Discovering Statistics Using SPSS, 3rd publishing. London: SAGE Publications.

Froese, F. J., Pak, Y. S. and Chong L. C., (2008), "Managing the Human Side of Cross-Border Acquisition in South Korea", Journal of World Business, 43, 97-108.

Gürsel, G., (2012), Expectation Based Evaluation Framework for Hospital Information Systems, Unpublished Doctoral Thesis, The Graduate School of Informatics of Middle East Thecnical University.

Hair, J. F., Anderson, R. E., Tatham, R. L., and Black, W. C., (1995), Multivariate Data Analysis With Readings (4th ed.), New Jersey: Prentice Hall.

Hair, J. F., Black, W. C., Babin, B. J. and Anderson, R. E., (2014), Multivariate Data Analysis, The United States of America: Pearson Education.

Hamersma, M., Heinen, E., Tillema, T. and Arts, J., (2016), “Residents' Responses to Proposed Highway Projects: Exploring The Role of Governmental Information Provision”, Transport Policy, 49, 56-67.

Hansen, T., (2003), "Intertype Competition: Specialty Food Stores Competing With Supermatkets”, Journal of Retailing and Consumer Services, 10, 35-49. 
Hinkin, T. R., (1995), “A Review of Scale Development Practices in The Study of Organizations”, Journal of Management, 21(5), pp. 967-988.

Hoyer, J. and Baum, K. B., (2012), "Prolonged Imaginal Exposure Based on Worry Scenarios", Exposure Therapy, 245-260.

Klump, K. and Butcher J. N., (1997), Psychological Tests in Treatment Planning: The Importance of Objective Assessment. In: J. N. Butcher, ed. Personality Asesment in Managed Health Care: Using the MMPI-2 in Treatment Planning, New York: Oxford University Press, pp. 93-130.

Kutanis, R. O. and Y1ldı, E, (2014), “The Relationship between Positive Psychology and Positive Organizational Behavior and an Evaluation on Positive Organizatinal Behavior Dimensions", The Journal of Visionary, 5(11), 135-154.

Künter, N. and Gürbüz, S. (2014). Askeri Liderlik: Kavramlaştırma ve Askeri Liderin Etkinliğinin Ölçümüne İlişkin Bir Ölçek Geliştirme Denemesi. 2. Örgütsel Davranış Kongresi Bildiriler Kitabı, 457-466, 07-08 Kasım 2014, Kayseri.

Lawshe C. H., (1975), “A Quantitative Approach to Content Validity”, Personnel Psychology, 28, 563-575.

Leech, N. L., Barrett, K. C. and Morgan, G. A., (2005), SPSS for Intermediate Statistics: Use and Interpretation, New Jersey: Lawrence Erlbaum Associates.

Luthans, F., (2002), “The Need for and Meaning of Positive Organizational Behavior”, Journal of Organizational Behavior, 23, 695-706.

Luthans, F., Luthans, K. W. and Luthans, B. C., (2004), "Positive Psychological Capital: Beyond Human and Social Capital", Business Horizons, 47(1), 45-50.

Luthans, F. and Youssef, C. M., (2004), "Human, Social, and Now Positive Psychological Capital Management: Investing in People for Competitive Advantage", Organizational Dynamics, 33(2), 143-160.

Portoghese, I., Galletta, M., Battistelli, A., Saiani, L., Penna, M. P. and Allegrini, E., (2012), “Change-Realted Expectations and Commitment to Change of Nurses: The Role of Leadership and Communication", Journal of Nursing Management, 20, 582-591.

Schmid, K., Phelps, E. and Lerner, R. M., (2011), "Constructing Positive Futures: Modeling The Relationship Between Adolescents' Hopeful Future Expectations and Intentional Self Regulation in Predicting Positive Youth Development", Journal of Adolescence, 34, 1127-1135.

Seligman, M. E. P., (2002), Positive Pschology, Positive Prevention, and Positive Theraphy. Handbook of Positive Psychology, edt. C. R. Snyder and Shane J. Lopez, New York: Oxford University Press, pp. 1-9.

Smith, R. C., Vogelgesang, G. and Avey, J., (2009), “Authentic Leadership and Positive Psychological Capital: The Mediating Role of Trust at The Group Level of Analysis”, Organizational Studies, 15(3), pp. $227-240$. 
Sutton, G. and Griffin, M. A., (2004) "Integrating Expectatins, Experiences, and Psycgological Contract Violations: A Longitudinal Study of New Professionals", Journal of Occupational and Organizational Psychology, 77, 493-514.

Tabachnick, B.G. and Fidell, L. S., (2007), Using Multivariate Statistics, The United States of America: Pearson Education Inc.

Tschacher, W., Junghan, U. M. and Pfammatter, M., (2014), "Towards a Taxonomy Of Common Factors in Psychotherap-Results of an Expert Survey”, Clinical Psychology and Psychotherapy, 21, 82-96.

Zarbo, C., Tasca, G. A., Cattafi, F. and Compare, A., (2016), "Integrative Psychoterapy Works", Frontiers in Psychology, 6, 1-3.

Zhou, T and Lu, Y., (2011), "Examining Mobile Instant Messaging User Loyalty from The Perspectives of Network Externalities and Flow Experience”, Computers in Human Behavior, 27, pp. 883-889. 


\section{APPENDIX 1.}

\section{Self-expectation for improvement in human issues}

SEOI 1. I believe that my relations with the manager of the unit I am affiliated with will strengthen in the future.

(Bağlı bulunduğum birimin yöneticisi ile olan ilişkilerimin gelecekte daha da güçleneceğine inaniyorum.)

SEOI 2. I think my relationship with other people working in the unit I'm working with will be better gradually.

(Şu anda çalışmakta olduğum birimde çalışan diğer insanlarla olan ilişkilerimin gittikçe daha iyi olacağını düşünüyorum.)

SEOI 3. I believe that I will do my work better as time goes on.

(Şu anda yapmakta olduğum işi, zaman ilerledikçe daha iyi yapacağıma inanıyorum.)

SEOI 4. In the future, I believe I will work in a higher status than the one I am currently working for. (Gelecekte, şu anda çalışmakta olduğum statüden daha yüksek bir statüde çalışacağıma inanıyorum.)

SEOI 5. I believe that I will be able to solve future problems related to my work. (İşimle ilgili ileride çıkabilecek sorunları çözebileceğime inanıyorum.)

SEOI 6. I think that the relations of the people in the unit I work with will be better in the future. (Çalışı̆̆ım birimdeki insanların birbirleriyle olan ilişkilerinin, gelecekte daha da iyi olacağını düşünüyorum.)

SEOI 7. Together with my colleagues, we love discovering new ways and methods of doing business and teaching them to each other.

(Çalışma arkadaşlarımla birlikte yeni iş yapma usülleri ve yöntemleri keşfetmeyi ve bunları birbirimize öğretmeyi seviyoruz.)

SEOI 8. I believe that the cooperation and solidarity in my unit will increase gradually. (Çalıştığım birimdeki işbirliği ve yardımlaşmanın giderek artacağına inanıyorum.)

SEOI 9. I believe that the contribution of the unit I work for will increase in the future.

(Çalıştığım birimin, kurumumuza olan katkısının gelecekte daha da artacağına inanıyorum.)

\section{Self-expectation for improvement in organizational issues}

SEOI 10. I can see that the general management style of the institution I work for has improved and will continue in the future.

(Çalıştığım kurumun genel yönetim biçiminin gittikçe geliştiğini ve bunun gelecekte de devam edeceğini görebiliyorum.)

SEOI 11. I think that instead of the current methods of doing business in my institution, there will be new and much more useful methods that will minimize the problems in the future.

(Kurumumda şu anda kullanılan iş yapma yöntemleri yerine, gelecekte sorunları en aza indirecek, yeni ve çok daha yararlı yöntemler geleceğini düşünüyorum.)

SEOI 12. I believe that the current structure and functioning of the institution I work for will be more effective and efficient in the future.

(Çalıştığım kurumun mevcut yapısının ve işleyişinin, gelecekte çok daha etkin ve verimli olacağına inaniyorum.)

SEOI 13. I believe that the institution I work for will produce more successful jobs in the future. (Çalıştı̆̆ım kurumun gelecekte çok daha başarılı işler çıkaracağına inanıyorum.)

SEOI 14. As an employee of this organization, I believe that everything will be much better in the future.

(Bu kurumun bir çalışanı olarak gelecekte her şeyin çok daha güzel olacağına inanıyorum.) 